\title{
The impact of remittances on economic growth in Bangladesh, India, Pakistan and Sri Lanka
}

\section{Soma Rani Sutradhar ${ }^{1,2}$}

Received: 15 July 2019 / Accepted: 16 January 2020 / Published online: 31 January 2020

(C) The Author(s) 2020

\begin{abstract}
This paper investigates the impact of workers' remittances on economic growth of four South Asian emerging countries by employing balanced panel data from 1977 to 2016. Pooled OLS, fixed effects, random effects and dummy variable interaction models are used to estimate the impact of remittances. The empirical regression analysis confirms a negative effect of remittances on economic growth in Bangladesh, Pakistan and Sri Lanka. Conversely, remittances have a positive impact on economic growth in India. This study also indicates a joint significant and negative relationship between remittances and economic growth in four countries.
\end{abstract}

Keywords Remittances $\cdot$ Economic growth $\cdot$ Panel data $\cdot$ South Asia $\cdot$ Emerging countries

$\begin{array}{ll}\text { Abbreviations } \\ \text { CLRM } & \text { Classical linear regression model } \\ \text { FDI } & \text { Foreign direct investment } \\ \text { FE } & \text { Fixed effects } \\ \text { GMM } & \text { Generalized method of moments } \\ \text { IMF } & \text { International monetary fund } \\ \text { IV } & \text { Instrumental variables } \\ \text { OLS } & \text { Ordinary least squares } \\ \text { RE } & \text { Random effects } \\ \text { WB } & \text { World Bank } \\ \text { WDI } & \text { World development indicators }\end{array}$

Soma Rani Sutradhar somasutradhar86@gmail.com

1 Department of Economics, Jatiya Kabi Kazi Nazrul Islam University, Trishal, Mymensingh 2224, Bangladesh

2 University of Leeds, Leeds LS2 9JT, United Kingdom 


\section{Introduction}

Remittances can be defined as the part of income of migrant workers who come back to the country of origin from the country of employment. According to the definition of International Monetary Fund (IMF), workers' remittances refer to the value of monetary transfers that is sent from the workers residing abroad for more than 1 year to the home country and are recorded in different sections of the balance of payments. Nowadays, remittances become an important and reliable source of external funding and capital accumulation in the developing economy [3].

In developing countries, remittances play an important role as a source of household income and are considered as a stable source [4]. In 2017, India was the largest remittance-receiving country, whereas Bangladesh was the eighth in the world [46-48]. Every year, South Asian migrant workers sent a significant amount of remittances which is an important source of economic development. Remittances are used to raise national savings, reduce the constraint associated with foreign exchange and balance of payments, and contribute to development budget. The remittances should be transferred through formal channels such as bank drafts, money transfer companies, and others to maximize the inflow of remittances. Informal channels like traders, friends or relatives without legal status should be avoided [27].

According to the neoclassical theory of migration, labor moves from low-wage countries to relatively high-wage countries because of wage differences among countries [23]. Remittances provide a way of poverty reduction and economic development when immigrants send remittances to the home country [49]. On the other hand, this type of migration to abroad could damage the development process when the home country loses highly educated and skilled workers which is called brain drain [41]. Thus, losses of human capital may affect economic growth negatively as reflected in the neoclassical growth theory.

Remittances may have adverse effects in the economic context. It may hamper economic growth through exchange rate appreciation thereby making it less competitive in international trade [35]. It may also inversely affect the labor supply decision of recipient families. Increase in remittances can be considered as an increase in non-labor income. Considering leisure as a normal good, households are expected to demand more leisure after receiving remittances in the form of non-labor income. The research of Rodriguez and Tiongson [36] indicates that remittances reduce the labor supply of receiving households in the Philippines. Thus, remittances have a negative impact on the labor supply decision of receiving family members, particularly female members [42]. It can raise inequality between families those are getting remittances and those are not. This procedure makes recipient families dependent on remittances and takes them away from productive activities. Most of the time, this money is used for consumption rather than productive investment [17].

The negative relationship between remittances and economic growth implies the altruistic motive of remittances while it specifies the productive motive if 
positively related. Sometimes, people use unofficial channels like Hundi and Hawala to reduce the sending cost of remittances which are called informal remittances. Political stability and better government laws are positively related to remittance inflow [1]. Usually, people use two types of channels to transfer funds: formal and informal. Government supervision and laws are associated with formal channels such as banks, postal services, money transfer operators and other wire transfer services. In most cases, these channels are related to high transaction costs and exchange loss. Hundi is the informal system used to send remittances to Bangladesh. Hundi and Hawala exist in Pakistan, whereas the Hawala system is known to India. Though Hundi is informal, it is organized comprising a network of relationships like friendship, kinship and regional attachment [33]. Favorable cost and speed of the informal channel Hawala lead to the migrants of Sri Lanka finding it more attractive than other formal channels [44].

Figure 1 shows the amount of remittances in 2017 of four countries. India was the top remittance-receiving country all over the world receiving $\$ 69.0$ billion in 2017. Bangladesh, Pakistan, and Nepal received \$13.5, \$19.7 and \$7.2 billion, respectively, in the same year [46-48]. In 2018, remittance growth is forecast at $3.1 \%, 2.5 \%, 2.4 \%$ and $2.2 \%$ for Bangladesh, India, Pakistan and Sri Lanka, respectively [45].

Figure 2 presents the trend of remittance inflows in four selected countries where India receives the highest amount of remittance among all countries and there is a sharp difference of remittance between India and other three countries as India is the top remittance receiver in the world. Pakistan and Bangladesh are the fifth and eighth remittance-receiving countries, respectively [45].

Figure 3 indicates the remittances as a percentage of GDP in Bangladesh, India, Pakistan, and Sri Lanka. In Bangladesh, the contribution of remittances on GDP increased till 2012 and after that, it reduced sharply. In India and Sri Lanka, the percentage of remittances in GDP increased gradually, while in Pakistan it shows a volatile trend.

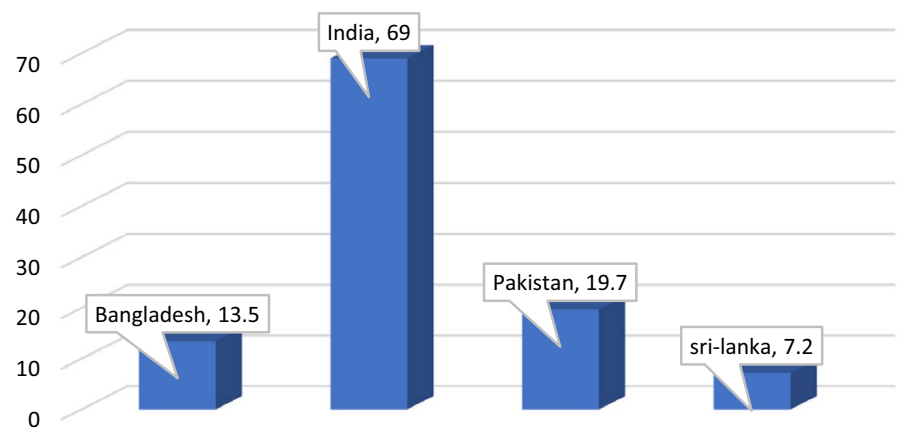

Fig. 1 Remittance inflows in 2017 (\$ billion). Source: Author's compilation using World Bank Data [4648] 


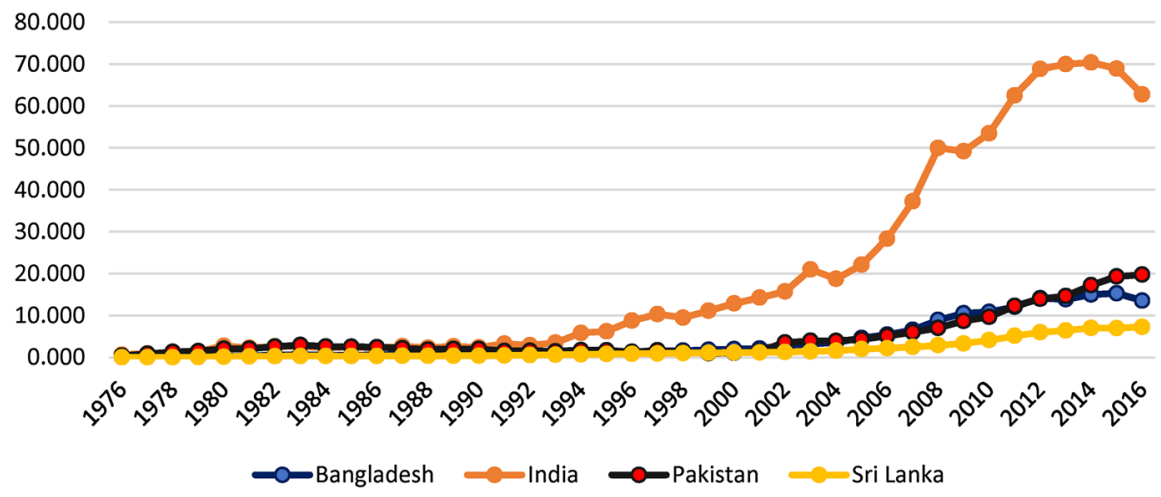

Fig. 2 Remittance inflows (\$ billion). Source: Author's compilation using World Bank Data [46-48]

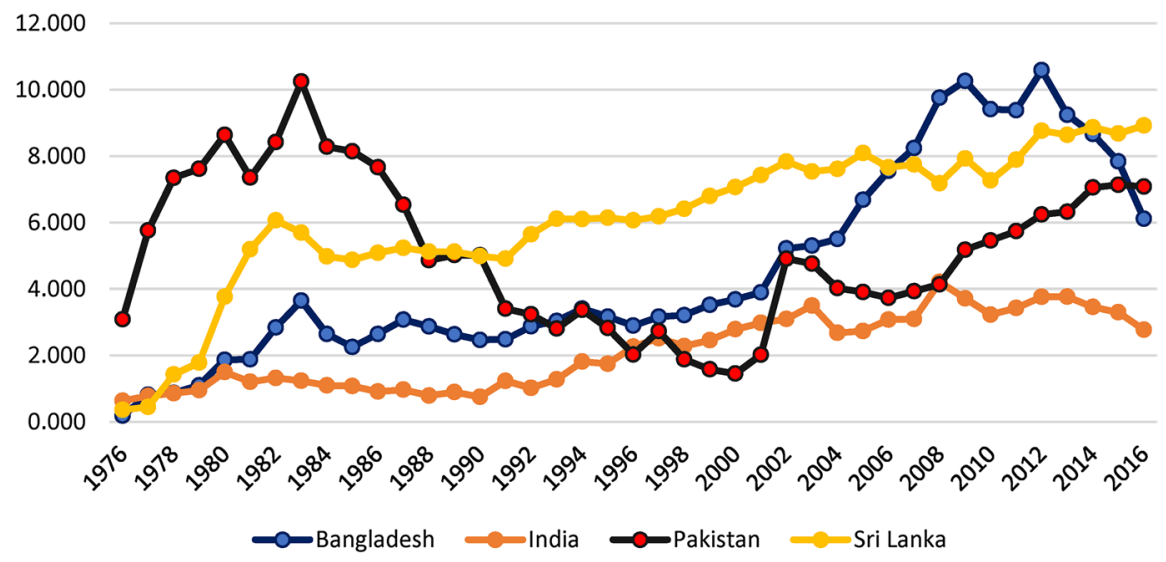

Fig. 3 Remittances (\% of GDP). Source: Author's compilation using World Bank Data [46-48]

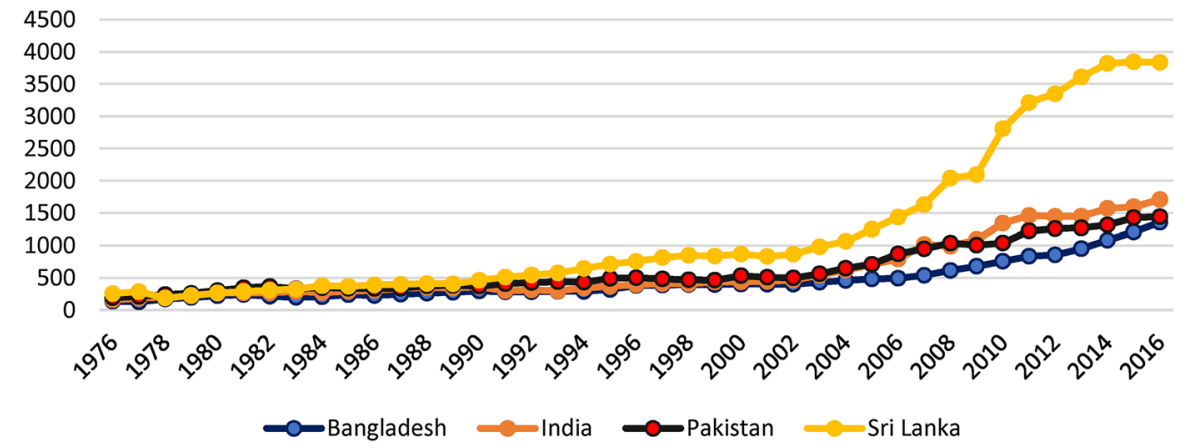

Fig. 4 Per capita GDP (\$). Source: Author's compilation using World Bank Data [46-48] 
Figure 4 implies the trend of per capita GDP (\$) of Bangladesh, India, Pakistan, and Sri Lanka. Sri Lanka shows a sharp increase in per capita GDP and it is higher than other three countries from 1984 to the current period.

This paper is concerned with the impact of remittances from four selected countries as these countries are emerging and receive a huge amount of remittances from all over the world whose productive utilization may raise economic growth. The purpose of this research is to examine whether remittances have a significant impact on economic growth in South Asian emerging countries. In this regard, this paper aims to find out the relationship between remittances and economic growth of these countries within the framework of neoclassical growth theory. Besides the joint impact, the individual impact of remittances in Bangladesh, India, Pakistan, and Sri Lanka and the comparison among these countries are also provided with the purpose of distinguishing the utilization of remittance inflows. To conduct this analysis, annual data of 40 years over the period 1977-2016 were collected from the World Bank and IMF database.

Country-specific analysis of remittances is added along with the overall impact of remittances in four emerging countries which implies the originality of this research, as most of the existing literature only provide the joint impact of remittances for developing or emerging countries. Initially, pooled ordinary least squares (OLS), fixed effects (FE) and random effects (RE) regressions are run to get the joint impact of remittances on economic growth for four emerging countries. Then, the dummy variable interaction model is used to identify the separate impact of each country. The F-test is also conducted to test the joint significance of interaction terms. Probability value indicates that interaction terms are jointly significant. Regression results show that the joint impact of remittances is negative and significant. The countryspecific dummy variable interaction model implies a negative impact of remittances in Bangladesh, Pakistan and Sri Lanka and positive impact in India.

The paper is structured as follows. "Literature review" briefly discusses the literature on the relationship between remittances and economic growth. It contains the positive, negative, mixed and neutral impact of remittances in different countries. "Methodology" explains the variables, data source, relevant models, methodology and empirical implementation of this study. "Empirical results" represent the results from the relevant estimation. Finally, "Conclusion" delivers the concluding remarks and recommendations.

\section{Literature review}

The aim of this paper is to analyze the relationship between workers' remittances and economic growth of four South Asian countries, as these countries receive enough remittances each year among which India is the top receiver of the world. There are many types of research on the impact of remittances. Since the paper focuses on economic growth, this section will review only the appropriate and related studies to get a better idea of the selected topic.

Pradhan et al. [30] analyzed the impact of workers' remittances on economic growth by employing panel data of 25 years from 39 developing countries for the 
period of 1980-2004 and found a positive and significant impact of remittances on economic growth. Fayissa and Nsiah [15] researched the influence of remittances on economic growth in 36 African countries over the period 1980-2004 and identified a positive relationship between remittances and economic growth. Ramirez [34] carried out a study which examined the impact of remittances on the economic growth, using panel data of 23 upper- and lower-income Latin American and Caribbean (LAN) countries for the period 1990-2007. He expressed the positive and significant impact of remittances on real per capita GDP growth. Topxhiu and Krasniqi [41] included six communist countries of Western Balkan (Albania, Kosovo, Macedonia, Montenegro, Bosnia and Herzegovina and Serbia) in their analysis for the period 2005-2015, using balanced panel data and found a positive impact of remittances on economic growth. Meyer and Shera [25] studied the various impacts that remittances have on the economic growth of six high remittances receiving countries, Albania, Bosnia Herzegovina, Bulgaria, Romania, Macedonia and Moldova using panel data set over the period 1999-2013. Regression results show a positive and significant contribution of remittances in the economic growth of the selected six countries. Comes et al. [12] explained the connection between remittances, foreign direct investment, and economic growth, using panel data from seven countries from Central and Eastern Europe covering the period 2010-2016. The empirical result expresses the positive effect of remittances and foreign direct investments on economic growth for all selected states.

Workers' remittance has a great contribution to the economic growth of Bangladesh [8, 11, 28, 43]. But Bangladesh still requires few improvements to remittances delivery system to avoid the informal channel to accept the remittances from migrants.

Remittances are the second largest factor of Pakistan economy. Worker's remittances and GDP growth in Pakistan over the period 1973-2011 are examined by Hussain and Anjum [19] and the empirical result shows the positive and significant relationship between remittances and GDP growth. Similarly, Ahmad et al. [2] assembled the data over the period 1980-2010 in Pakistan where a strong positive association between workers remittances and per capita GDP is found.

Cooray [13] found a positive and significant relationship between remittances and economic growth in South Asia by employing panel data over the period 1970-2008. Azam [7] examined the role of remittances in fostering economic growth in Bangladesh, India, Pakistan and Sri Lanka and found the positive impact of remittances on economic growth in all countries. Another study was conducted by Jawaid and Raza [21] for five South Asian countries using long time series data for the period 1975-2009 and concluded that remittances have a long run positive and significant influence on economic growth in Bangladesh, India, Sri Lanka, and Nepal, while it is significant but negative in Pakistan.

Conversely, Chami et al. [10] included 113 countries in their research and concluded that remittances have a negative impact on GDP growth using panel data of 29 years over the period 1970-1998. They found a negative correlation between the remittance's growth and economic growth. They identified the role of remittances as an altruistic which is not profit driven. Karagoz [22] carried out a study which examined the relationship between workers' remittances and 
economic growth in Turkey, using the time series data from the year 1970-2005. The empirical results found a negative association between remittances and economic growth in Turkey. Ferdaous [16] concluded that only a smaller portion of the remittances received in developing countries are used for productive purposes, using a panel dataset of 33 developing countries for the period 2003-2014.

In another study, Oshota and Badejo [26] investigated the impact of remittances on economic growth in Nigeria for the period 1981-2011. Researchers found a positive impact of remittances on the economic growth of Nigeria in the long run. On the other hand, in the short run, a negative relationship exists between remittances and economic growth. Pradhan [29] has used balanced panel data for five emerging economies such as Brazil, India, China, South Africa and Russian Federation over the period 1994-2013 to examine the relationship between remittances and the economic growth of these countries. He found a positive relationship between remittances and economic growth in China. The study also showed a significant and negative impact of remittances on economic growth in Brazil, India and Russian Federation. The impact of remittances on economic growth is positive and statistically insignificant in South Africa. Tolcha and Rao [40] analyzed the short-run and long-run impact of remittances on the economic growth of Ethiopia for the period 1981-2012. The result shows the significant and negative impact of remittances on GDP in the long run, whereas remittances have a significant and positive relationship on the economic growth in the short run.

Hasan and Shakur [17] had worked on a dataset of Bangladesh for the years 1976-2012 and identified a non-linear relationship between remittances and per capita GDP growth. They found a negative growth effect of remittances at first and the effect became positive at a later stage.

Besides these studies, Barajas et al. [9] concluded that workers' remittances do not have any impact on economic growth in developing countries by employing the panel dataset of 84 countries over the period from 1970 to 2004.

Shaikh et al. [37] aimed to analyze the relationship between remittances and economic growth of Pakistan using time series data of 35 years for the period 1980-2014. Researchers found that personal remittances have no effect on economic growth of Pakistan.

The above-explained literature mainly focuses on the effects of remittances on the developing or emerging economies. Researchers found different impacts of remittances like positive, negative, mixed and neutral. Most of these papers identified either only the joint impact of a group of countries or impact of an individual country. They did not analyze both impacts. Further studies should focus on these both aspects of the effects of remittances. This paper provides the joint impact of remittances of four South Asian emerging countries as previous studies but also provides an additional contribution to the existing literature by introducing a dummy variable interaction model. Individual impacts of each country are also identified with this model. 


\section{Methodology}

The empirical implementation of the models used in this research and related tests are discussed in this section. Most of the studies on panel data regression based on developing or emerging countries show the average impact of remittances on economic growth but do not show individual effects. Few studies show the individual impact on a single country using time series data. The aim of this research is to identify both the magnitude of the average impact of remittances for four South Asian countries on per capita GDP growth and their impact in Bangladesh and other countries. A comparison of the impact among four countries will also be made later. The joint significance of individual effects will be done using $F$-test. The concept of neoclassical growth model like Solow-Swan growth model is used here to express the relationship between per capita GDP growth and remittances growth.

\section{Econometric approach}

\section{Models}

Meyer and Shera [25] and Topxhiu and Krasniqi [41] used the same methodology for their research related to remittances and economic growth. They have applied pooled OLS, fixed effects and random effects models for empirical analysis. These researchers only found the average impact of remittances and other explanatory variables on the economic growth. This paper can be differentiated from their works as here interaction terms are used to specify the country-specific impacts of remittances and the combined effect of remittances is also calculated for the four South Asian countries.

The pooled OLS, FE and RE models are used here which are the appropriate models for panel data. After that, a simple dummy variable interaction model is employed. Panel data models are as follows:

$$
\begin{gathered}
(\mathrm{gdppcg})_{i t}=\alpha+\beta(\mathrm{remg})_{i t}+\gamma^{\prime} Z_{i t}+\varepsilon_{i t} \\
(\mathrm{gdppcg})_{i t}=\alpha+\mu_{i}+\theta_{t}+\beta(\mathrm{remg})_{i t}+\gamma^{\prime} Z_{i t}+\varepsilon_{i t} \\
(\mathrm{gdppcg})_{i t}=\alpha+\mu_{i}+\theta_{t}+\beta(\mathrm{remg})_{i t}+\delta D_{i t} \times(\mathrm{remg})_{i t}+\gamma^{\prime} Z_{i t}+\varepsilon_{i t}
\end{gathered}
$$

where $(\mathrm{gdppcg})_{i t}$ is the gross domestic product per capita growth, $\mu_{i}$ is the country-specific, time-invariant effect, $\theta_{t}$ is the time-specific, country-invariant effect, $(\text { remg })_{i t}$ is the growth in remittances, and $Z_{i t}$ is the vector of explanatory variables (growth in foreign direct investment, growth in exports of goods and services, growth in exchange rate against USD, growth in gross capital formation). Subscript (i) represents countries $(i=1,2, \ldots \mathrm{N})$, where $N=4$. Subscript $(t)$ represents time $(t=1,2, \ldots T)$, where $T=40 . \varepsilon_{i t}$ represents an error term. 
The error term is iid (independent and identically distributed), with zero mean and constant variance.

Heterogeneous effects of the four countries are addressed here by introducing the interaction term of country dummy and remittance in the model. Country dummy for each country is generated and interaction terms are created.

\section{Research hypotheses}

The research hypothesis implies that remittance coefficient is not statistically different from zero, whereas the alternative hypothesis indicates that it is statistically different from zero. Remittances can be considered as capital accumulation which is statistically significant and increases economic growth [25]. On the other hand, results may differ because of the lack of productive investment, and remittances play an altruistic role rather than profit driven [16]. Chami et al. [10] found such negative impact of remittances on GDP growth as remittances may reduce the labor supply and labor force participation rate of recipients. Thus, moral hazard problems are created from such non-labor income. "The moral hazard problem created by remittances can be severe enough to reduce economic activity. Our empirical estimations reveal considerable evidence both that remittances tend to be compensatory in nature and they have negative affects on economic growth" ([20], p. 21). Existing literature provides both positive and negative values of remittance coefficient against the null hypothesis. The above-discussed models will check the coefficient value of remittances. This research is attempted to find the answer of few research questions such as whether the inflow of remittances in these four countries have a significant impact on economic growth. It also tries to find the nature and magnitude of the impact of remittances. Finally, a comparison is made among these four countries in this regard.

Thus, the null and the alternative hypotheses of this research are as follows:

$$
\begin{aligned}
& \mathrm{H}_{0}: \beta=0 \\
& \mathrm{H}_{A}: \beta \neq 0
\end{aligned}
$$

\section{Empirical implementation}

In the first step of estimation, the parameters of Eq. (1) are estimated by pooled OLS model assuming no time-specific effect and constant country-specific effect. Then, the parameters of Eq. (2) are estimated by the fixed effects model which controls the correlation between individual effects and explanatory variables. After that, the estimation of Eq. (2) is obtained using the random effects model where it is assumed that the individual effects are uncorrelated with the regressors.

In the second step, pooled OLS, FE, and RF regressions are run for dummy variable interaction model as indicated by Eq. (3).

In the third step, necessary tests are conducted to take a decision about which one is the best model among pooled OLS, fixed effects and random effects models. 
Hausman test is conducted to select a model between RE and FE models. Then, to choose between pooled OLS and random effects, Breusch-Pagan LM test is used. Finally, we get the value of $F$-statistics from the Stata table of FE model, to check the unobserved heterogeneity.

\section{Variable selection and measurement}

Economic growth models relate capital accumulation with growth. Solow [38] and Swan [39] developed the neoclassical growth model that was the foundation of advanced growth theory. This model attempts to relate the economic growth with capital accumulation [14].

In this research, nominal variables are used for the empirical analysis and discussion purpose. The growth rate of each variable is calculated and used for estimation purpose. Thus, dependent and all explanatory variables are expressed in percentage form. The monetary value of these variables is expressed in USD. The exchange rate is measured in each country's domestic currency against USD.

In this research, capital accumulation is presented in the form of remittance earning where remittance growth is the main explanatory variable and GDP per capita growth is the dependent variable. Control variables are chosen based on related empirical growth literature and those are suggested by the neoclassical growth models. Foreign direct investment (FDI) growth, gross capital formation (GCF) growth, exports growth and exchange rate growth are the control variables considered for this analysis.

In this study, remittance means the portion of migrant workers income that they send to home countries. Here, FDI means the net inflow of foreign direct investment that implies the value of a direct investment that comes from the foreigners or non-resident investors to the reporting or home country. GCF means the monetary amount that is added to fixed assets plus the net change in inventories. Equipment, machinery, plant, and buildings are considered as fixed assets and inventory includes those goods which are partially completed and remain in production. Export means one country's export earnings from goods and services. The exchange rate is the value of the domestic currency in terms of USD. GDP per capita implies per person's gross domestic product in a country.

FDI, GCF, and export earnings are also related to capital accumulation. Exchange rate against USD is another explanatory variable whose growth implies a devaluation of the domestic currency. As a result, more domestic currencies are required to import the same amount of goods. Currency devaluation is also related to weakening the economic strength of the domestic country in international trade though it may increase exports. The overall impact will depend on demand elasticities of exports and imports and other trade policies. This variable is indirectly related to international capital inflow or outflow to a country.

Related studies frequently used explanatory variables from these variables to justify the impact of remittances on economic growth. Pradhan [29] used remittances, export, and exchange rate as explanatory variables in his paper to investigate the association among remittances, export, exchange rate and economic growth in 
emerging economies. Gross capital formation (GCF), remittances and foreign direct investment (FDI) are considered as explanatory variables in the study of Ferdaous [16] to express the relationship between remittances and GDP per capita.

From the database of the World Bank (WB) and International Monetary Fund (IMF), all data are gathered. GDP per capita, the net inflow of FDI, export, and GCF are collected from the World Development Indicator (WDI) of the World Bank. Exchange rate data are taken from the International Financial Statistics (IFS) of the International Monetary Fund (IMF). The source of remittance data is the WB which is calculated by the staff of WB based on IMF and WB country desks.

\section{Sample selection}

This paper investigates the relationship between remittances and economic growth in four South Asian emerging countries, namely Bangladesh, India, Pakistan, and Sri Lanka. These four countries are sampled since all of them are emerging and have available data and information on per capita GDP, remittances, and other control variables.

A joint significant impact of remittances is expected in these countries as a huge amount of remittances is received in these countries each year. India was the top remittance-receiving country in the world in 2017 ( $\$ 69.0$ billion), while Pakistan and Bangladesh were in fifth and eighth position. For this analysis, data from four countries have been collected from the database of the IMF and WB.

For this research, a panel dataset for 40 years in the period 1977-2016 is used containing information from four countries. Here, countries represent the cross-sectional units. It is a strongly balanced panel since the period is the same for each country. Panel data from four countries are used over the period 1976-2016 to measure the effect of remittances on economic growth for these individual emerging countries. These countries earn a significant amount of remittances each year among which India is the largest remittance receiving country in the world [45]. The average impact of the panel is also specified to get an idea of overall South Asia. Thus, we can understand the present scenario, identify the obstacles and make suggestions for further improvement.

\section{Theoretical background: remittances and growth theories}

Remittance inflows have a large impact on the growth rate of productive capacity in the receiving countries. This section examines how the inflows of remittances exert such impacts through different channels.

\section{Remittance inflows and capital accumulation}

Remittance inflows may stimulate investment in capital accumulation. Remittance recipient households can increase the accumulation rate of physical and human 
capital [9]. Remittances also stimulate capital accumulation by raising funds to the investors [21].

\section{Remittance inflows and labor force growth}

Rate of growth of labor inputs may increase as a result of remittance receipts. It is expected that remittance receipts have a negative effect on labor force participation addressing the moral hazard problem as the recipient families treat the inflows as non-labor income [9].

\section{Remittance inflows and total factor productivity growth}

Remittances may affect total factor productivity growth through effects on the efficiency of domestic investment. Remittances inflows may appreciate real exchange rate. This implies Dutch disease effects in remittance-receiving countries. These effects may happen if equilibrium real exchange rate appreciation results in the contraction of production sectors that generate dynamic production externalities [9].

\section{Empirical results}

This part attempts to discuss the stationarity tests, the estimated coefficients of selected models, endogeneity, sensitivity analysis and robustness of the core model. At the first part of estimation, parameters of Eq. (1) are estimated by the pooled OLS model. Fixed effects and random effects models are used to estimate the coefficients of Eq. (2). Using dummy variable interaction model introduced in the last chapter, the second part of the estimation process is started. To obtain a model which best fits the data and produces robust results, numerous forms of Eq. (3) are tested. For three different models namely pooled OLS, fixed effects and random effects, the panel regression is run. Finally, the Hausman [18] test and Breusch-Pagan LM test are conducted to select the best model among these three models. Before going through these procedures, all the variables are checked by unit root tests to examine whether these are stationary or not. Other diagnostic tests such as multicollinearity, heteroscedasticity, and autocorrelation are also performed.

\section{Stationarity and other tests}

Stationarity test of variables is the important part of the empirical analysis. In this study, unit root methods namely Fisher ADF (Augmented Dickey-Fuller) and Fisher PP (Phillips-Perron) are used.

Table 1 represents the results of both Fisher-type ADF and PP tests. Two different forms are used to get a clear idea about stationarity of all variables. The same testing procedure is run with and without trend. Test results confirm the stationarity at a level for all the explanatory variables including the dependent variable per capita GDP growth. So, these variables are integrated of degree $0, I(0)$. 
Table 1 Panel unit root test result Source: Author's own calculations

\begin{tabular}{|c|c|c|c|c|c|}
\hline \multirow[t]{3}{*}{ Variables } & \multicolumn{4}{|l|}{ At level } & \multirow{3}{*}{$\begin{array}{l}\text { Order of } \\
\text { integra- } \\
\text { tion }\end{array}$} \\
\hline & \multicolumn{2}{|c|}{ Fisher type (ADF) } & \multicolumn{2}{|c|}{ Fisher type (PP) } & \\
\hline & $C$ & CT & $C$ & $\mathrm{CT}$ & \\
\hline gdppcg & $27.049 * * *$ & $15.838^{* * *}$ & $188.113^{* * *}$ & $162.494 * * *$ & I (0) \\
\hline remg & $38.402 * * *$ & $30.573 * * *$ & $181.834 * * *$ & $175.520 * * *$ & I (0) \\
\hline fdig & $60.474 * * *$ & $51.087 * * *$ & $288.349 * * *$ & $288.349 * * *$ & $\mathrm{I}(0)$ \\
\hline gcfg & $32.963 * * *$ & $21.449 * * *$ & $151.304 * * *$ & $125.861 * * *$ & $\mathrm{I}(0)$ \\
\hline expg & $27.921 * * *$ & $19.601 * *$ & $193.162 * * *$ & $180.005^{* * *}$ & $\mathrm{I}(0)$ \\
\hline excg & $29.373 * * *$ & $17.455^{* *}$ & $101.187 * * *$ & $89.124 * * *$ & $\mathrm{I}(0)$ \\
\hline
\end{tabular}

$C$ indicates the specification with intercept; CT means specification with intercept and trend. Values with $* * *, * *$ and $*$ are significant at $1 \%, 5 \%$ and $10 \%$ level of significance

Multicollinearity, autocorrelation and heteroscedasticity tests are conducted. There is no multicollinearity among the explanatory variables. Test results conclude that there are no heteroscedasticity and autocorrelation of residuals at $5 \%$ level of significance.

For the dummy variable interaction model, there is no collinearity among independent variables including interaction terms. The probability value of Wooldridge autocorrelation test is 0.903 which is larger than the level of significance (0.05). So, we do not reject the null hypothesis of no first-order autocorrelation. Thus, there is no serial correlation in the residual. Probability value for the Breusch-Pagan/ Cook-Weisberg test for heteroskedasticity (0.016) is smaller than the level of significance (0.05). So, we can reject the null hypothesis of constant variance and accept the presence of heteroscedasticity. Another test of heteroscedasticity named by White's test is also conducted. The probability value for this test is 0.001 and we can reject the null hypothesis of homoscedasticity at $5 \%$ or $1 \%$ level of significance. Both tests show the presence of heteroscedasticity of residuals. To fight against heteroscedasticity and get the unbiased result, robust regression is used for this analysis.

\section{Main results}

Table 2 represents the coefficients of explanatory variables of pooled OLS, fixed effects, and random effects regressions which confirm the negative and significant impact of remittances growth on GDP per capita growth in South Asian countries.

After running these three regressions, Hausman [18] test is conducted and it is seen that the fixed effects model becomes a better choice than the random effects model. Then, the Breusch-Pagan LM test is conducted and it is found that the pooled OLS is the better choice over random effects model. These results are similar to the research work of Topxhiu and Krasniqi [41]. Finally, we need to consider F-test where the null hypothesis of no unobserved heterogeneity can be rejected at $5 \%$ level of significance. This implies the presence of unobserved heterogeneity and fixed effects model is preferable to a pooled OLS model. In the fixed effects model, 
Table 2 Results of pooled OLS, fixed effects, and random effects models. Dep. variable: gdppcg Source: Author's own calculations

\begin{tabular}{llll}
\hline Variable & Pooled OLS & Fixed effects & Random effects \\
\hline remg & $-0.035^{* * *}(0.009)$ & $-0.033 * * *(0.009)$ & $-0.035^{* * *}(0.009)$ \\
fdig & $-0.000^{* *}(0.000)$ & $-0.000(0.000)$ & $-0.000^{* *}(0.000)$ \\
excg & $-0.395^{* * *}(0.049)$ & $-0.418^{* * *}(0.048)$ & $-0.395^{* * *}(0.049)$ \\
gcfg & $0.360^{* * *}(0.028)$ & $0.349 * * *(0.028)$ & $0.360^{* * *}(0.028)$ \\
expg & $0.073 * * *(0.028)$ & $0.082^{* * *}(0.027)$ & $0.073 * * *(0.028)$ \\
Constant & $4.838^{* * *}(0.662)$ & $4.988^{* * *}(0.652)$ & $4.838^{* * *}(0.662)$ \\
$R^{2}$ & 0.757 & 0.756 & 0.757 \\
Observations & 160 & & \\
No. of countries & 4 & & \\
Hausman test $(\mathrm{RE}$ vs FE) $(p$ value $)$ & $25.70(0.000)$ & & \\
Breusch-Pagan LM test (pooled & $0.00(1.000)$ & & \\
$\quad$ OLS vs RE) $(p$ value) & & & \\
\hline
\end{tabular}

Values with $* * *, * *$ and $*$ are significant at $1 \%, 5 \%$ and $10 \%$ level of significance. Standard errors are reported in parenthesis

the $R^{2}$ value is 0.756 meaning that $75.6 \%$ variations in per capita GDP growth are explained by the explanatory variables.

So, fixed effects model is the appropriate model among the three models and the coefficients of this model are explained here. The results of the fixed effects model indicate that a $1 \%$ increase in remittance growth leads to $0.033 \%$ decrease in GDP per capita growth in South Asian emerging countries. On the other hand, FDI impact of these countries is statistically insignificant and negligible. It has a negative impact which is close to zero as the net inflow data of FDI is used here. When a given amount of FDI comes to these countries, simultaneously the existing foreign companies may return their investment to the home country. Higher political instability, the lake of rules and regulations in the domestic country are responsible for improper use of FDI. This finding can be related to the research of Topxhiu and Krasniqi [41]. Capital accumulation is required for economic growth. A $1 \%$ increase in GCF growth results in $0.349 \%$ increase in GDP per capita growth. This result is consistent with the study of Ferdaous [16]. Export earnings are a prominent source of international currency inflow in emerging countries. Coefficient value implies that a $1 \%$ increase in export growth increases GDP per capita growth by $0.082 \%$. The exchange rate is very crucial in terms of international trade, as it plays an important role to determine the value of domestic currency. A $1 \%$ increase in the growth of the exchange rate reduces economic growth by $0.418 \%$. These two results of exports and exchange rate are consistent with the analysis of Pradhan [29].

Table 3 represents the robust results of Pooled OLS, fixed effects, and random effects regressions for the dummy variable interaction model which confirms the negative and significant impact of remittances on GDP per capita growth in Bangladesh. 
Table 3 Robust results of dummy variable interaction model Source: Author's own calculations

\begin{tabular}{llll}
\hline Indicator & Pooled OLS & Fixed effects & Random effects \\
\hline remg (Bangladesh) & $-0.055^{* * *}(0.008)$ & $-0.051^{* * *}(0.002)$ & $-0.055^{* * *}(0.005)$ \\
Interaction 2 (India) & $0.072^{* * *}(0.027)$ & $0.092^{* * *}(0.002)$ & $0.072^{* * *}(0.008)$ \\
Interaction 3 (Pakistan) & $0.034(0.021)$ & $0.031^{* * *}(0.003)$ & $0.034^{* * *}(0.004)$ \\
Interaction 4 (Sri Lanka) & $0.051(0.035)$ & $0.010(0.027)$ & $0.051^{* *}(0.024)$ \\
fdig & $-0.000^{* * *}(0.000)$ & $-0.000^{* *}(0.000)$ & $-0.000^{* * *}(0.000)$ \\
excg & $-0.418^{* * *}(0.047)$ & $-0.396^{* * *}(0.058)$ & $-0.418^{* * *}(0.068)$ \\
gcfg & $0.342^{* * *}(0.042)$ & $0.353^{* *}(0.073)$ & $0.342^{* * *}(0.077)$ \\
expg & $0.081^{* * *}(0.026)$ & $0.086^{* *}(0.026)$ & $0.081^{* * *}(0.024)$ \\
Constant & $4.817^{* * *}(0.610)$ & $4.599^{* *}(0.884)$ & $4.817^{* * *}(1.371)$ \\
$R^{2}$ & 0.771 & 0.765 & 0.771 \\
Observations & 160 & & \\
No. of countries & 4 & & \\
Cluster-robust Hausman test (RE vs & $10.14(0.255)$ & & \\
FE) $(p$ value) & & & \\
Breusch-Pagan LM test (pooled OLS & $0.00(1.000)$ & & \\
$\quad$ vs RE) & & & \\
$(p$ value) & & & \\
\hline
\end{tabular}

Values with $* * *, * *$ and $*$ are significant at $1 \%, 5 \%$ and $10 \%$ level of significance. Robust standard errors are reported in parenthesis

After running the three regressions, pooled OLS, fixed effects and random effects for dummy variable interaction model, we need to choose the appropriate one with the help of Hausman [18] test and Breusch-Pagan LM test. Cluster-Robust Hausman test is used for the analysis with robust regression, as the Hausman test is not applicable for heteroscedasticity. By doing so, we decide to choose the random effects model over fixed effects model. Finally, Breusch-Pagan LM test is conducted and it is concluded that pooled OLS is the better choice over random effects model. These results are similar to the research work of Topxhiu and Krasniqi [41]. The $R^{2}$ value of the pooled OLS model is 0.771 which implies that explanatory variables can explain $77.1 \%$ variations of per capita GDP growth.

Pooled OLS model is the appropriate model in terms of dummy variable interaction model and the coefficients of this model are explained here. Interaction terms show the marginal effect of remittances for each country. Here, Bangladesh is the base country. In India, the impact of remittances growth on economic growth is $0.07 \%$ higher than Bangladesh. In Pakistan and Sri Lanka, it is $0.03 \%$ and $0.05 \%$, respectively, higher than Bangladesh.

The result of pooled OLS indicates that a $1 \%$ increase in remittance growth leads to a $0.05 \%$ decrease in GDP per capita growth in Bangladesh. In India, this impact is positive, but it is also negative in Pakistan and Sri Lanka. A 1\% increase in remittance growth increases $0.017 \%$ and reduces $0.021 \%$ and $0.004 \%$ per capita GDP growth in India, Pakistan and Sri Lanka, respectively. Of these four countries, India is the top remittance receiver in the world [46-48] and the positive impact of remittances in India implies the more productive use of remittances 
than the other three countries. On the other hand, FDI impact of these countries is statistically significant but it is negligible. It has a negative impact but is close to zero as the net inflow data of FDI is used for this research. In every year, FDI comes to these countries from different countries, whereas remaining companies may withdraw their investment. As a result, the net inflow of FDI may be negative if the amount of outflow is higher than the amount of new investment. A large number of factors are responsible for hampering positive outcomes from foreign direct investment in Bangladesh, like inadequate infrastructure, a slow-moving privatization process, an unskilled labor force, inefficient bureaucracy, political instability, and recurring natural disasters [32]. This finding can be related to the research of Azam [7], where the researcher found the negative and significant impact of FDI on economic growth. Gross capital formation can be considered as capital accumulation which is helpful for economic growth. A 1\% increase in GCF growth results in $0.342 \%$ increase in GDP per capita growth. Ferdaous [16] also found the same relation between GCF and economic growth. Export earnings play an important role in international trade in developing countries. A $1 \%$ increase in export growth increases GDP per capita growth by $0.081 \%$. The exchange rate determines the value of the domestic currency in terms of foreign currencies that affect international trade. A $1 \%$ increase in the growth of the exchange rate reduces economic growth by $0.418 \%$. These two results of exports and exchange rate are consistent with the analysis of Pradhan [29].

Lastly, to check the joint significance of interaction terms, F-test is performed. The $P$ value of $F$-test is 0.000 , thus null hypothesis can be rejected at $5 \%$ level of significance and it can be concluded that country-specific remittance coefficients are jointly statistically significant.

\section{Endogeneity}

To justify omitted variable bias which may arise from unobserved heterogeneity, cross-sectional effects can be included [6]. Country-specific effects are included in this analysis. Fixed effects model is considered for this study to incorporate and control unobserved heterogeneity. The problem of endogeneity can be solved using instrumental variables (IV) estimation and generalized method of moments (GMM) estimation. GMM estimators are biased when the sample size is small because of the correlation between the moments and the weight matrix [5].

It is very difficult to find out an instrumental variable which is strongly related to the exposure. In case of a weak instrument or small correlation between the instrumental variable and the exposure, the IV estimator may contain large standard error. Instrumental variables (IV) estimator will be biased in a small sample. A small violation of the main assumptions of the instrumental variable will result in a biased estimation of IV even if the sample size is large [24]. In this paper, the sample size is not too small, but it is not large enough to use IV or GMM estimator. So, the fixed effects (FE) model is a better option for this research as IV or GMM requires a large sample to get unbiased estimators. 


\section{Sensitivity and robustness}

The behavior of core regression coefficient estimates can be checked by adding or removing regressors to the main regression as a sensitivity test. Few experiments are provided with additional or fewer control variables. The model is re-estimated after excluding countries one by one with replacement. In each case, most of the estimates are largely unaffected in sign, size, and significance. So, most coefficient estimates of fixed effects model are less sensitive to such changes.

There is no multicollinearity among the explanatory variables for the fixed effects model. No first-order autocorrelation in the residuals and no heteroscedasticity of residuals are also confirmed. Different regression specifications imply the same conclusion of the negative relationship between remittances and the economic growth as the core model. Thus, this model can be considered as a robust model.

The same testing procedure is done for the dummy variable interaction model where pooled OLS is chosen. Inclusion and exclusion of control variables and exclusion of countries in turns do not affect largely most of the coefficient estimates in size, sign, and significance and are less sensitive to changes of regression specification. Robust standard errors can fight against heteroscedasticity and provide unbiased estimators. There is no multicollinearity and first-order autocorrelation in this model. This model is a robust model as again results get the same finding of the core model.

After conducting different tests, a negative relationship is found between remittances and economic growth across four South Asian emerging countries. This relationship is statistically significant. In Bangladesh, the impact of remittances on economic growth is also negative and statistically significant. Unproductive use of remittances may lead to negative economic growth. It may reduce labor supply also, as few families are getting money in the form of remittances without any work. Sometimes remittances come through the improper channel and account for any a smaller amount than the original. These types of constraints are also responsible for adverse effects of remittances in the South Asian economy. By increasing the use of the proper channel and the productive use of remittances, these four countries may enhance their economic growth.

\section{Conclusion}

The main purpose of this research is to analyze how remittances affect per capita GDP growth in four countries of South Asia using the annual panel data over the period 1977-2016. The regression results express a negative relationship between remittances and economic growth in South Asian countries except in India. The empirical result indicates that a $1 \%$ increase in remittance growth leads to 0.05 , 0.021 and $0.004 \%$ decrease and $0.017 \%$ increase in GDP per capita growth in Bangladesh, Pakistan, Sri Lanka and India, respectively. The negative result suggests that a larger portion of remittances are used for non-productive purposes like consumption. This tendency of spending indicates the altruistic motive of remittances rather than profit driven. In India, remittances are used for productive 
purposes. Thus, it reflects profit-generating activities regarding remittance inflows. Other control variables such as FDI growth and exchange rate growth are statistically significant and negatively related to economic growth, while growth in exports and gross capital formation are also significant but have a positive impact on per capita GDP growth.

Remittances can raise domestic consumption and reduce poverty which is beneficial for the South Asian countries. The inflow of remittances may raise the income level of the poor people and help to reduce the poverty. Thus, remittances are more beneficial in case of poverty reduction rather than the economic growth [35]. Besides these, there are some adverse effects of migration. Brain drain effect depresses the average level of skilled and educated workers in worker sending countries. Thus, higher migrating countries reflect slow economic growth compared to countries with lower migration rates [49]. The moral hazard problem may be created by remittances which could weaken the incentive to work for recipient families. This tendency may reduce economic activity. Policymakers should convince both remitters and the recipients to invest a larger portion of the remittance flows for the productive purpose [10]. Remittance inflow appreciates the real exchange rate and decreases international trade competitiveness of a country, which in turn deteriorates the economy. Thus, the inflow of remittances affects inversely the economy of a country through this process known as Dutch disease. By raising the trade competitiveness, the government can reduce the adverse Dutch disease effect of remittance flows [31].

Dummy variable interaction model creates additional insights into this paper, as this helps to separate the country-specific individual impact of remittances. To search and estimate remittances through informal channels and its contribution to economic growth are beyond the scope of this paper. For further studies, datasets for an extended period and more countries may give a better and more robust analysis. In addition, more control variables could be included that have a specific impact on economic growth such as variables related to human capital, migration and brain drain. Identification and estimation of remittances through informal channels may give a clear idea about the actual amount of remittances. In the future studies, researchers should focus on informal channels of receiving remittances. Governments and policymakers of these South Asian emerging countries should put more emphasis on migration policies, and require amendment for the proper implication of these policies and the productive use of remittances to secure economic growth.

Acknowledgements I would like to thank my thesis supervisor Dr. Peter Phelps for his remarkable suggestions and valuable comments on my work during the whole thesis period. His guideline and support made me confident and proficient while preparing this paper. Furthermore, I wish to express my gratitude to my family members for their motivation and support to overcome all the obstacles and complete this paper successfully.

Author contributions It is important that I am the only author of this article. I am responsible for all works including all editions. I have read and approved the final manuscript.

Funding I have received research grant of $£ 225$ from Commonwealth Scholarship Commission.

Availability of data and material Data and other necessary materials will be available on request. 


\section{Compliance with ethical standards}

Conflict of interest The author declares that she has no competing interests.

\section{Summary statistics}

\begin{tabular}{|c|c|c|c|c|c|}
\hline Variable & Obs & Mean & Std. dev. & Min & $\operatorname{Max}$ \\
\hline gdppcg & 160 & 6.394796 & 8.600143 & -34.60198 & 34.02547 \\
\hline remg & 160 & 17.59928 & 35.57083 & -31.35291 & 320.4141 \\
\hline gcfg & 160 & 10.38026 & 13.94895 & -29.52897 & 67.51273 \\
\hline fdig & 160 & -694.1734 & 9651.567 & -121956.7 & 3081.768 \\
\hline expg & 160 & 10.09731 & 13.65796 & -34.8794 & 86.67552 \\
\hline excg & 160 & 5.956454 & 8.160279 & -8.737004 & 75.93779 \\
\hline interaction 1 & 160 & 5.795014 & 27.67525 & -22.05156 & 320.4141 \\
\hline interaction 2 & 160 & 3.520864 & 12.69199 & -16.52391 & 91.85386 \\
\hline interaction 3 & 160 & 3.386036 & 16.85752 & -31.35291 & 143.258 \\
\hline interaction4 & 160 & 4.897367 & 16.84768 & -3.087956 & 152.559 \\
\hline
\end{tabular}

Data description Secondary data are used for this research. From the database of the World Bank (WB) and International Monetary Fund (IMF), all data are gathered. GDP per capita, the net inflow of FDI, export, and GCF are collected from the World Development Indicator (WDI) of the World Bank. Exchange rate data are taken from the International Financial Statistics (IFS) of the International Monetary Fund (IMF). The source of remittance data is the WB which is calculated by the staff of WB based on IMF and WB country desks.

Open Access This article is licensed under a Creative Commons Attribution 4.0 International License, which permits use, sharing, adaptation, distribution and reproduction in any medium or format, as long as you give appropriate credit to the original author(s) and the source, provide a link to the Creative Commons licence, and indicate if changes were made. The images or other third party material in this article are included in the article's Creative Commons licence, unless indicated otherwise in a credit line to the material. If material is not included in the article's Creative Commons licence and your intended use is not permitted by statutory regulation or exceeds the permitted use, you will need to obtain permission directly from the copyright holder. To view a copy of this licence, visit http://creativecommons.org/licen ses/by/4.0/.

\section{References}

1. Abbas, F., Masood, A., \& Sakhawat, A. (2017). What determine remittances to Pakistan? The role of macroeconomic, political and financial factors. Journal of Policy Modeling, 39(3), 519-531.

2. Ahmad, M., Ilyas, M., \& Abdul Rehman, C. (2016). The impact of workers' remittances on economic development of Pakistan. Oman Chapter of Arabian Journal of Business and Management Review, 34(92), 1-7.

3. Al-Assaf, G., \& Al-Malki, A. M. (2014). Modelling the macroeconomic determinants of workers' remittances: The case of Jordan. International Journal of Economics and Financial Issues, 4(3), 514-526.

4. Alfieri, A., Havinga, I., \& Hvidsten, V. (2005). Definition of remittances and relevant BPM5 flows, Department of Economic and Social Affairs. New York: Statistics Division, United Nations. 
5. Altonji, J. G., \& Segal, L. M. (1996). Small-sample bias in GMM estimation of covariance structures. Journal of Business and Economic Statistics, 14(3), 353-366.

6. Arestis, P., \& Phelps, P. (2015). Endogeneity analysis of output synchronization in the current and prospective EMU. JCMS: Journal of Common Market Studies, 54(3), 525-543.

7. Azam, M. (2015). The role of migrant workers remittances in fostering economic growth: The four Asian developing countries' experiences. International Journal of Social Economics, 42(8), 690-705.

8. Barai, M. K. (2012). Development dynamics of remittances in Bangladesh. Sage Open, 2(1), 2158244012439073.

9. Barajas, A., Gapen, M. T., Chami, R., Montiel, P., \& Fullenkamp, C. (2009). Do workers' remittances promote economic growth? (No. 2009-2153). International Monetary Fund.

10. Chami, R., Fullenkamp, C., \& Jahjah, S. (2005). Are immigrant remittance flows a source of capital for development? IMF Staff papers, 52(1), 55-81.

11. Chowdhury, M. B. (2011). Remittances flow and financial development in Bangladesh. Economic Modelling, 28(6), 2600-2608.

12. Comes, C. A., Bunduchi, E., Vasile, V., \& Stefan, D. (2018). The impact of foreign direct investments and remittances on economic growth: A case study in Central and Eastern Europe. Sustainability, 10(1), 1-16.

13. Cooray, A. (2012). The impact of migrant remittances on economic growth: Evidence from South Asia. Review of International Economics, 20(5), 985-998.

14. Dohtani, A. (2010). A growth-cycle model of Solow-Swan type, I. Journal of Economic Behavior \& Organization, 76(2), 428-444.

15. Fayissa, B., \& Nsiah, C. (2010). The impact of remittances on economic growth and development in Africa. The American Economist, 55(2), 92-103.

16. Ferdaous, J. (2016). Impact of remittances and FDI on economic growth: A panel data analysis. Journal of Business Studies Quarterly, 8(2), 58-77.

17. Hasan, G. M., \& Shakur, S. (2017). Nonlinear effects of remittances on per capita GDP growth in Bangladesh. Economies, 5(3), 1-11.

18. Hausman, J. A., 1978. Specification tests in econometrics. Econometrica: Journal of the Econometric Society, 46(6), 1251-1271.

19. Hussain, R., \& Anjum, G. A. (2014). Worker's remittances and GDP growth in Pakistan. International Journal of Economics and Financial Issues, 4(2), 376-381.

20. Jahjah, M. S., Chami, M. R., \& Fullenkamp, C. (2003). Are immigrant remittance flows a source of capital for development? (No. 3-189). International Monetary Fund.

21. Jawaid, S. T., \& Raza, S. A. (2016). Effects of workers' remittances and its volatility on economic growth in South Asia. International Migration, 54(2), 50-68.

22. Karagoz, K. (2009). Workers' remittances and economic growth: Evidence from Turkey. Journal of Yasar University, 4(13), 891-1908.

23. Kurekova, L. (2011) Theories of migration: Conceptual review and empirical testing in the context of the EU East-West flows. In Interdisciplinary Conference on Migration. Economic Change, Social Challenge (pp. 6-9).

24. Martens, E. P., Pestman, W. R., Boer, A. D., Belitser, S. V., \& Klungel, O. H. (2006). Instrumental variables: Application and limitations. Epidemiology, 17(3), 260-267.

25. Meyer, D., \& Shera, A. (2017). The impact of remittances on economic growth: An econometric model. Economia, 18(2), 147-155.

26. Oshota, S. O., \& Badejo, A. A. (2014). The impact of remittances on economic growth in Nigeria: An error correction modeling approach. Zagreb International Review of Economics \& Business, $17(2), 21-43$.

27. Ozaki, M. (2012). Worker migration and remittances in South Asia. South Asia Working Paper Series. Asian Development Bank.

28. Paul, B. P., \& Das, A. (2011). The remittance-GDP relationship in the liberalized regime of Bangladesh: Cointegration and innovation accounting. Theoretical and Applied Economics, 9(9), 41-60.

29. Pradhan, K. C., 2016. Does remittance drive economic growth in emerging economies: Evidence from FMOLS and Panel VECM. Theoretical \& Applied Economics, 23(4), 57-74.

30. Pradhan, G., Upadhyay, M., \& Upadhyaya, K. (2008). Remittances and economic growth in developing countries. The European journal of development research, 20(3), 497-506.

31. Rabbi, F., Chowdhury, M. B., \& Hasan, M. Z. (2013). Macroeconomic impact of remittances and the Dutch disease in a developing country. American Journal of Economics, 3(5C), 156-160. 
32. Rahman, A. (2015). Impact of foreign direct investment on economic growth: Empirical evidence from Bangladesh. International Journal of Economics and Finance, 7(2), 178-185.

33. Rahman, Md M, \& Yeoh, B. S. A. (2008). The social organization of Hundi'. Asian Population Studies, 4(1), 5-29.

34. Ramirez, M. D. (2013). Do financial and institutional variables enhance the impact of remittances on economic growth in Latin America and the Caribbean? A panel cointegration analysis. International Advances in Economic Research, 19(3), 273-288.

35. Ratha, D. (2013). The Impact of remittances on economic growth and poverty reduction. Migration Policy Institute, Policy Brief. No. 8.

36. Rodriguez, E. R., \& Tiongson, E. R. (2001). Temporary migration overseas and household labour supply: Evidence from Urban Philippines. The International Migration Review, 35(3), 709-725.

37. Shaikh, G. M., Tariq, M., \& Shakri, I. H. (2016). Remittances and economic growth in Pakistan: A time series analysis. Global Management Journal for Academic \& Corporate Studies, 6(2), 36-48.

38. Solow, R. M., 1956. A contribution to the theory of economic growth. The Quarterly Journal of Economics, 70(1), 65-94.

39. Swan, T. W., 1956. Economic growth and capital accumulation. Economic Record, 32(2), 334-361.

40. Tolcha, T. D., \& Rao, P. N. (2016). The impact of remittances on economic growth in Ethiopia. Indian Journal of Commerce and Management Studies, 7(2), 1-15.

41. Topxhiu, R. M., \& Krasniqi, F. X. (2017). The relevance of remittances in fostering economic growth in The West Balkan countries. Ekonomika, 96(2), 28-42.

42. Vargas-Silva, C., Jha, S., \& Sugiyarto, G. (2009). Remittances in Asia: Implications for the fight against poverty and the pursuit of economic growth. ADB Economics Working Paper Serie. No. 182, Asian Development Bank.

43. Wadood, S. N., \& Hossain, Md. A. (2015). Impact of overseas remittances on economic growth: Evidences from Bangladesh. Munich Personal RePEc Archive. Paper No. 81657, https://mpra. ub.uni-muenchen.de/81657/. The Dhaka University Studies [Journal of the Faculty of Arts], 70(1), 93-111.

44. World Bank. (2005). Migrant labour remittances in South Asia. Washington, DC.

45. World Bank. (2017). Migration and development brief 28. Washington, DC.

46. World Bank (2018). Migration and development brief 29. Washington, DC.

47. World Bank. (2018). World bank open data. [online]. Available at: https://data.worldbank.org/. Accessed 28 June 2018.

48. World Bank. (2018). Migration and remittances data. [online] Available at: http://www.worldbank. org/.../migrationremittancesdiasporaissues/.../migration-remittances-d. Accessed Apr 2018.

49. World Bank \& Asian Development Bank. (2018). Migration and remittances for development in Asia. Washington: DC, Metro Manila.

Publisher's Note Springer Nature remains neutral with regard to jurisdictional claims in published maps and institutional affiliations. 